DOI: https://doi.org/10.15407/techned2018.04 $: \underline{061}$

\title{
FEATURES OF DISCONTINUOUS CONTROL OF A FREQUENCY CONVERTER IN A SINGLE-PHASE NON-AUTONOMIC POWER SUPPLY NETWORK UNDER THE CONDITION OF THE TRANSFORMER'S NON-IDEALITY
}

Journal

Publisher

ISSN

Issue

Pages
Tekhnichna elektrodynamika Institute of Electrodynamics National Academy of Science of Ukraine 1607-7970 (print), 2218-1903 (online)

No 4, 2018 (July/August)

$61-64$

\section{Authors}

\section{Mysak T.V. *, Mykhalskyi V.M. **}

Institute of Electrodynamics National Academy of Sciences of Ukraine,

pr. Peremohy, 56, Kyiv, 03057, Ukraine,

e-mail: taras@igbt.com.ua

* ORCID ID : http://orcid.org/0000-0002-3140-971X

** ORCID ID : http://orcid.org/0000-0002-8251-3111

\begin{abstract}
The object of the study is a sinusoidal voltage source that includes a generator operating from solar panels, a semiconductor frequency converter with an output $L C$ filter and a nonlinear single-phase transformer at the output connected to a single-phase supply network. A description of this system is obtained in the form of a nonlinear singularly perturbed system of differential equations, for which reduction is carried out. Nonlinearity is reduced to a form that allows the synthesis of discontinuous control. The stability problems and features inherent in
\end{abstract}


discontinuous control in this system are considered. The results of modeling, carried out taking into account the limitations that affect the technical feasibility of implementing the obtained control law, are presented. References 10, figure 1.

Key words: frequency converter, transformer with saturation, integral manifold, discontinuous control, singularly perturbed system, stability.

Received: 05.03 .2018

Accepted: 06.03.2018

Published:

\section{References}

1. Teodorescu R., Liserre M., Rodriguez P. Grid Converters for Photovoltaic and Wind Power Systems. Hoboken, NJ, USA: John Wiley \& Sons Ltd, 2011. 407 p. DOI: https://doi.org/10.100 2/9780470667057

2. Bourguiba I., Houari A., Belloum H., Kourda F. Control of Single-Phase Grid Connected Photovoltaic Inverter. Proceedings of 2016 4th International Conference on Control Engineering \& Information Technology

(CEIT-2016). Tunisia, Hammamet- December, 16-18, 2016. Pp. 1-6. DOI: https://doi.org/10.1109/CEIT.2016.7929116

3. Mykhalskyi V.M. Means for improving the quality of electricity at the input and output of frequency and voltage converters with pulse-width modulation. Kyiv, Instytut Elektrodynamiky NAN Ukrainy, 2013. 340 p. (Ukr)

4. Yang Y., Blaabjerg F. Overview of Single-Phase Grid-Connected Photovoltaic Systems. Elec tric Power Components and Systems , 2015. 99(PP). Pp. 1-10. DOI:

https://doi.org/10.1080/15325008.2015.1031296 
5. Matyuk V.F., Osipov A.A. Mathematical models of the magnetization curve and magnetic hysteresis loops. Part I. Nerazrushaiushchii kontrol i diagnostika. 2011. No 2. Pp. 1-33. (Rus) 6. Mysak T.V. Construction of output voltage modulation for power supply with non-linear output transformer by the reduced order mathematical model. Pratsi Instytutu elektrodynamiky NAN Ukrainy . 2017. No 47. Pp.

57-67. (Ukr)

7. Voropayeva N.V., Sobolev V.A. Geometric decomposition of singularly perturbed systems. Moskva: Fizmatlit, 2009. 256 p. (Rus)

8. Yolkin V.I. Reduction of nonlinear control systems. Differential-geometric approach. Moskva: Nauka, 1997. 317 p. (Rus)

9. Utkin V.I., Guldner J., Jingxin Shi. Sliding Mode Control in Electro-Mechanical Systems.

Second Edition. By Taylor \& Francis Group LLC, 2009. 486 p. DOI: https://doi.org/10.1201/97 81420065619

10. Quality of electrical energy. NKREKP. http://www.nerc.gov.ua/?id=19529 . (Ukr)

$\underline{\text { PDF }}$ 